\title{
ANALISIS YURIDIS PERJANJIAN PEMBIAYAAN KONSUMEN DAN AKIBAT HUKUM JIKA TERJADI WANPRESTASI DALAM PERJANJIAN PEMBIAYAAN KONSUMEN DI INDONESIA*
}

\author{
UMUL KHAIR \\ Sekolah Tinggi Ilmu Hukum Putri Maharaja, \\ J1.Inai Belakang SPBU Koto Nan IV Payakumbuh \\ email: khair_ummul78@yahoo.com
}

\begin{abstract}
In Article 1329 of the Civil Code, the agreement is divided into 2 (two) kinds, namely the named agreement (nominaat) and unnamed agreement (innominaat). Contracts or agreements develope at this time as a logical consequence of the development of business cooperation between business actors. In a treaty there is one part bind itself to another part. Consumer financing is an agreement not specifically regulated in the Civil Code, but since the book III of the Civil Code embraces an open system, parties may enter into agreements not specifically regulated in the Civil Code. The consumer financing agreement as an Innominaat agreement is also subject to general terms of agreement. In this study using normative research methods, where the authors can examine and can also learn the norms contained in legislation or norms that regulated the principle of freedom of contract according to the Civil Code so that in its implementation in accordance with applicable regulations. The results show how the implementation of consumer financing agreements in Indonesia and how the legal consequences in case of default in consumer financing agreements. First, basically the consumer financing agreement in Indonesia is conducted like other agreements in general. Consumer Financing Agreement is not like a sale or purchase agreement or a lease, but the consumer financing agreement is a combination of both applicable by the parties exercising the rights and obligations in the agreement as described above. Second, the result of the law in case of default, the agreement does not need to be requested for cancellation, but by itself has been null and void, but the provisions of Article 1266 paragraph 2 explain that the consequences of the law of default are not null and void, but must be annulled to the judge. Subsequently Article 1244-Article 1252 of the Criminal Code describes the compensation for default, namely, by paying the actual losses suffered, the fees used, and allowed to cease the expected loss of profits.
\end{abstract}

Keywords: Agreement, Consumer Financing, Legal Consequences, Wanprestasi

\section{Abstract}

Dalam Pasal 1329 KUH Perdata, perjanjian dibedakan menjadi 2 (dua) macam, yaitu perjanjian bernama (nominaat) dan perjanjian tidak bernama (innominaat). Kontrak atau perjanjian berkembang pada saat ini sebagai konsekuensi yang logis dari berkembangnya kerjasama bisnis antar pelaku bisnis. Dalam suatu perjanjian itu terdapat satu pihak mengikatkan dirinya kepada pihak lain. Pembiayaan konsumen adalah perjanjian yang tidak diatur secara khusus dalam KUH Perdata, tetapi oleh karena buku III KUH Perdata menganut sistem terbuka, maka para pihak boleh membuat perjanjian yang tidak diatur secara khusus dalam KUH Perdata. Dengan demikian perjanjian Pembiayaan konsumen sebagai suatu perjanjian Innominaat juga tunduk kepada ketentuan umum tentang perjanjian. Dalam penelitian ini menggunakan metode penelitian normatif, dimana penulis dapat meneliti dan dapat pula mempelajari norma-norma yang terdapat dalam peraturan perundang-undangan ataupun norma yang mengatur tentang Asas kebebasan berkontrak menurut KUH Perdata sehingga dalam pelaksanaanya sesuai dengan peraturan yang berlaku. Hasil penelitian menunjukkan tentang bagaimana penerapan perjanjian Pembiayaan konsumen di Indonesia dan bagaimana akibat hukum jika terjadi wanprestasi dalam perjanjian Pembiayaan konsumen. Pertama, pada dasarnya perjanjian Pembiayaan konsumen di Indonesia dilakukan seperti perjanjian-perjanjian lain pada umumnya. Perjanjian Pembiayaan

${ }^{*}$ Naskah diterima: 31 Agustus 2017, direvisi: 11 Sebtember 2017, disetujui untuk terbit: 14 Sebtember 2017 
Umul Khair: Analisis Yuridis Perjanjian Pembiayaan Konsumen Dan Akibat Hukum....

konsumen bukan seperti perjanjian jual beli ataupun sewa menyewa, namun perjanjian Pembiayaan konsumen merupakan gabungan dari keduanya yang diaplikasikan dengan cara para pihak melakukan hak dan kewajiban dalam perjanjian seperti yang telah dijelaskan sebelumnya. Kedua, akibat hukumnya jika terjadi wanprestasi, maka perjanjian tersebut tidak perlu dimintakan pembatalan, tapi dengan sendirinya sudah batal demi, namun ketentuan Pasal 1266 ayat 2 menjelaskan bahwa akibat hukum wanprestasi tidak batal demi hukum, namun harus dimintakan pembatalan kepada hakim. Selanjutnya Pasal 1244- Pasal 1252 KUHPerdata menjelaskan mengenai ganti rugi atas wanprestasi yaitu, dengan membayar kerugian nyata yang dialami, ongkos-ongkos yang digunakan, serta dibolehkan untuk menuntuk kehilangan keuntungan yang di harapkan.

Kata kunci: Perjanjian, Pembiayaan Konsumen, Akibat Hukum, Wanprestasi

\section{PENDAHULUAN}

Perjanjian Pembiayaan konsumen adalah perjanjian yang tidak diatur secara khusus dalam Kitab Undang-Undang Hukum Perdata, tetapi oleh karena buku III Kitab Undang-Undang Hukum Perdata menganut system terbuka, maka para pihak boleh membuat perjanjian yang tidak diatur secara khusus dalam Kitab Undang Undang Hukum Perdata. Dengan demikian Perjanjian Pembiayaan konsumen beli sebagai suatu perjanjian Innominaat juga tunduk kepada ketentuan umum tentang perjanjian. Dan merupakan jenis perjanjian baru dalam praktek di Indonesia sehingga bentuk perjanjian ini telah menjadi pranata hukum yang berlaku dan diakui oleh masyarakat serta telah menjadi yurisprudensi meskipun belum diatur dengan undang-undang. Perjanjian Pembiayaan konsumen berkembang sebagai perjanjian yang berdasarkan kebiasaan dan kebutuhan bisnis. ${ }^{1}$

Perjanjian Pembiayaan konsumen merupakan suatu perjanjian timbal balik dan merupakan perjanjian innominaat. Perjanjian Pembiayaan konsumen di

1 Suharnoko, Hukum Perjanjian Teori Dan Analisa Kasus, Prenada Media, Hlm. 64-65
Indonesia dapat dikatakan baru, karena muncul dengan mengikuti perkembangan jaman. Namun secara yuridis dalam Perjanjian Pembiayaan konsumen masih kurang dipahami secara jelas. Sehubungan dengan hal tersebut di atas, dalam penentuan akibat hukum yang terjadi oleh karena suatu perbuatan melawan hukum ataupun wanprestasi yang dilakukan oleh salah satu pihak tentunya perlu penjelaskan secara lebih rinci oleh karena mengingat bahwa Perjanjian Pembiayaan konsumen merupakan kontrak Innominaat, yang pengaturannya tidak tercantum dalam peraturan perundang-undangan secara khusus, sehingga penerapan akibat hukumnya pula kurang jelas.

Dalam praktik memang tidak mudah untuk menentukan hukum mana yang berlaku dalam perjanjian campuran seperti Perjanjian Pembiayaan konsumen.Namun kenyataannya Perjanjian Pembiayaan konsumen banyak diterapkan dalam kegiatan bisnis misalnya Perjanjian Pembiayaan konsumen kendaraan bermotor. Pelaksanaannya biasanya dilakukan dengan perjanjian tertulis tapi juga ada yang dilakukan tidak tertulis, semua 
tergantung para pihak yang membuatnya, adapula yang dilakukan dengan perjanjian baku, namun adapula isi perjanjiannya dilakukan secara negosiasi kemudian dituangkan dalam perjanjian tertulis. Oleh karena itu dengan adanya buku III KUHPerdata yang menganut asas kebebasan berkontrak/system terbuka, maka para pihak bebas menentukan jenis perjanjian, dengan siapa dia harus mengadakan kontrak, objek kontrak, serta menentukan format kontrak, asalkan semuanya tidak bertentangan dengan undang-undang, kepentingan umum, kesusilaan/moral dan kepatutan.

Dari kenyataan tersebut pasti akan banyak masalah yang muncul oleh karena perjanjian tersebut berlakunya baru di Indonesia, sehingga banyak masyarakat yang belum mengerti dan memahami penerapan perjanjian tersebut, bahkan penetapan risikonya, sehingga pasti akan muncul ketidak seimbangan antara para pihak khususnya bagi debitur.Sehubungan dengan hal tersebut diatas penulis tertarik untuk mengetahui bagaimana penerapan dan akibat hukum Perjanjian Pembiayaan konsumen di Indonesia, sehingga penulisan karya ilmiah ini berjudul "ANALISA YURIDIS PERJANJIAN PEMBIAYAAN KONSUMEN DAN AKIBAT HUKUM JIKA TERJADI WANPRESTASI DALAM PERJANJIAN PEMBIAYAAN KONSUMEN DI INDONESIA"

\section{METODE PENELITIAN}

Dalam penelitian ini dapat menggunakan metode penelitian Yuridis Normatif, dimana penulis dapat meneliti dan dapat pula mempelajari normanorma yang terdapat dalam peraturan perundang-undangan ataupun norma yang mengatur tentang Asas kebebasan berkontrak menurut KUH Perdata sehingga dalam pelaksanaanya sesuai dengan peraturan yang berlaku. Untuk melengkapi dan mendukung serta memperjelas suatu analisis terhadap peraturan perundang-undangan dapat juga diteliti tulisan-tulisan dari ahli yang terdapat dalam kepustakaan.

\section{HASIL DAN PEMBAHASAN}

\section{A. Perjanjian pembiayaan konsumen di Indonesia}

\section{Mekanisme Pelaksanaa Perjanjian Pembiayaan Konsumen di Indonesia}

Berdasarkan Peraturan Pesiden Republik Indonesia Nomo 9 tahun 2009 tentang lembaga pembiayaan bahwa Pembiayaan Konsumen (Consumer finance) adalah kegiatan pembiayaan untuk pengadaan barang berdasarkan kebutuhan konsumen dengan pembayaran secara angsuran dan harus melalui tahap-tahap yang telah ditetapkan sebagai berikut:

1. Tahap Permohonan Untuk dapat memperoleh fasilitas pembiayaan konsumen berupa barang-barang yang dibutuhkan oleh konsumen, debitur (konsumen) biasanya sudah mempunyai usaha yang baik dan 
Umul Khair: Analisis Yuridis Perjanjian Pembiayaan Konsumen Dan Akibat Hukum....

atau mempunyai pekerjaan yang tetap serta berpenghasilan yang memadai.

Adapun syarat-syarat yang harus dipenuhi oleh debitur (konsumen) untuk dapat mengajukan permohonan fasilitas pembiayaan konsumen, yaitu:

a. Copy KTP calon peminjam

b. Copy KTP suami/isteri calon peminjam

c. NPWP (Nomor Pokok WajibPajak)

d. Kartu Keluarga/Surat Nikah bagi konsumen yang telah menikah

e. Slip gaji atau Surat Keterangan Gaji (jika calon peminjam bekerja)

f. Rekening Listrik/Rekening Telepon/Rekening Air (PDAM)

g. Surat Keterangan lainnya yang diperlukan

Permohonan pembiayaan konsumen biasanya dilakukan oleh debitur (konsumen) ditempat dealer/supplier penyedia kendaraan bermotor kebutuhan konsumen yang telah bekerjasama dengan perusahaan pembiayaan.

2. Tahap Pengecekan dan Pemeriksaan Lapangan

Berdasarkan aplikasi dari pemohon, Marketing Departement akan melakukan pengecekan atas kebenaran dari pengisian formulir aplikasi tersebut dengan melakukan analisa dan evaluasi terhadap data dan informasi yang telah diterima, yang kemudian dilanjutkan dengan kunjungan ke tempat calon peminjam (plan visit), melakukan pengecekan ke tempat lain (credit checking) dan. melakukan observasi secara umum/khusus lainnya. Tujuan dari pemeriksaan lapangan adalah untuk memastikan keberadaan debitur dan memastikan akan barang kebutuhan konsumen, untuk mempelajari keberadaan barang kebutuhan konsumen yang dibutuhkan oleh debitur terutama harga kredibilitas supplier/pemasok dan layanan purna jual, untuk menghitung secara pasti berapa besar tingkat kebenaran laporan calon debitur dibandingkan dengan laporan yang telah disampaikan.

\section{Tahap Pembuatan Customer Profile}

Berdasarkan hasil pemeriksaan lapangan, Marketing Department akan membuat Customer Profile yang isinya akan menggambarkan tentang:

a. Nama calon debitur dan isteri/suami

b. Alamat dan nomor telepon

c. Nomor KTP

d. Pekerjaan

e. Alamat Kantor

f. Kondisi Pembiayaan yang diajukan.

g. Jenis dan tipe barang kebutuhan konsumen

4. Tahap Pengajuan Proposal Kepada Kredit Komite

Pada tahap ini Marketing Department akan mengajukan proposal terhadap permohonan yang diajukan oleh debitur kepada Kredit Komite. Proposal yang diajukan biasanya terdiri dari:

a. Tujuan pemberian fasilitas pembiayaan konsumen.

b. Struktur fasilitas pembiayaan yang mencakup harga barang, uang 
muka, bunga, jangka waktu, tipe dan jenis barang.

c. Latar belakang debitur disertai dengan keterangan mengenai kondisi pekerjaan dan lingkungan tempat tinggalnya.

d. Analisa Resiko.

e. Saran dan Kesimpulan.

5. Keputusan Kredit Komite

Keputusan Kredit Komite merupakan dasar bagi kreditur untuk melakukan pembiayaan atau tidak. Apabila permohonan debitur ditolak maka harus diberitahukan melalui surat penolakan, sedangkan apabila disetujui maka Marketing Department akan meneruskan tahap berikutnya.

6. Tahap Pengikatan

Berdasarkan keputusan Kredit Komite, bagian Legal biasanya akan mempersiapkan pengikatan sebagai berikut:

a. Perjanjian Pembiayaan Konsumen beserta lampiran- lampirannya.

b. Jaminan Pribadi (jika ada)

c. Jaminan Perusahaan (jika ada)

Pengikatan perjanjian pembiayaan konsumen dapat dilakukan secara bawah tangan yang dilegalisir oleh notaris atau dapat dikatakan secara notariil.

\section{Tahap Pemesanan Barang Kebutuhan Konsumen}

Setelah proses penandatanganan perjanjian dilakukan oleh kedua belah pihak, selanjutnya kreditur akan melakukan hal-hal sebagai berikut: a. Kreditur melakukan pemesanan barang kepada supplier, pesanan mana dituangkan dalam Penegasan Pemesanan Pembelian (Confirm Purchase Order), Bukti Pengiriman dan Surat Tanda Penerimaan Barang.

b. Khusus untuk obyek pembiayaan bekas pakai, seperti Use Motor Cycle (UMC) akan dilakukan pemeriksaan BPKB oleh Credit Administration Department.

c. Penerimaan Pembayaran dari debitur kepada kreditur (dapat melalui supplier/dealer) yang meliputi:

1. Pembayaran Pertama, antara lain: uang muka, angsuran pertama (jika in advance), premi asuransi untuk tahun pertama, biaya administrasi, dan pembayaran pertama lainnya jika ada.

2. Pembayaran berikutnya yang meliputi: angsuran berikutnya berupa cheque/bilyet giro mundur, pembayaran premi asuransi untuk tahun berikutnya, dan pembayaran lainnya jika ada.

8. Tahap Pembayaran Kepada Supplier

Setelah barang diserahkan supplier kepada debitur selanjutnya supplier akan melakukan penagihan kepada kreditur dengan melampirkan: kuitansi penuh, kuitansi uang muka dan atau bukti pelunasan uang muka, confirm purchase order, bukti pengiriman dan surat tanda penerimaan barang, gesekan nomor rangka dan mesin, surat pernyataan BPKB, kunci duplikat dan surat jalan (jika ada). Sebelum pembayaran barang dilakukan oleh kreditur kepada supplier, 
hal-hal yang akan dilakukan oleh kreditur adalah:

a. Melakukan penutupan pertanggungan asuransi ke perusahaan asuransi yang telah di tunjuk.

b. Melakukan pemeriksaan ulang seluruh dokumentasi perjanjian pembiayaan konsumen oleh Credit/Legal Administration Department dengan mempergunakan Form Check List Document.

9. Tahap Penagihan atau Monitoring Pembayaran

Setelah seluruh proses pembayaran kepada supplier/dealer dilakukan, proses selanjutnya adalah pembayaran angsuran dari debitur sesuai dengan jadwal yang telah ditentukan. Adapun sistim pembayaran yang dapat dilakukan yaitu: dengan cara cash, cheque/bilyet giro, transfer dan ditagih langsung. Perlu diketahui bahwa penentuan sistem pembayaran angsuran telah ditentukan pada waktu marketing process dilakukan. Monitoring pembayaran angsuran dilakukan oleh Collection Department berdasarkan jatuh tempo pembayaran yang telah ditentukan dan berdasarkan sistim pembayaran yang diterapkan. Perlu dijelaskan bahwa monitoring oleh kreditur tidak terbatas hanya pada monitoring pembayaran angsuran dari debitur, akan tetapi kreditur juga melakukan monitoring terhadap jaminan, jangka waktu berlakunya jaminan dan masa berlakunya penutupan asuransi.
10. Pengambilan Surat Jaminan

Apabila seluruh kewajiban debitur telah dilunasi, maka kreditur akan mengembalikan kepada debitur: jaminan (BPKB, dan atau sertifikat dan atau invoice/faktur beserta dokumen lainnya jika ada).

\section{a. Syarat-Syarat Dalam Pengajuan Pembiayaan Konsumen}

Berdasarkan ketentuan baku yang dituangkan dalam fomulir, untuk dapat mengajukan permohonan kredit pembiayaan konsumen baik harus memenuhi persyaratan-persyaratan yang telah ditetapkan Adapun persyaratan umum yang harus dipenuhi oleh konsumen perorangan dalam pengajuan kredit tersebut adalahsebagai beriku:

a. Untuk pemohon pegawai swasta/karyawan berusia antara 21 sampai 55 tahun (sampai dengan akhir tenor) dan untuk pemohon wiraswasta berusia 21 sampai 60 tahun (sampai dengan akhir tenor) atau yang berusia dibawah 21 tahun tetapi sudah menikah.

b. Pemohon suami/isteri memiliki pekerjaan atau usaha yang tetap,jelas, legal maksudnya bahwa usaha tersebut jelas terlihat dan tidak bertentangan dengan hukum yang berlaku, yaitu: tempat pekerjaan tidak berpindah-pindah dan menekuni satu bidang usaha dan tidak berganti-ganti.

c. Tidak memproses pemohon yang tidak memiliki usaha/pekerjaan yang jelas, walaupun pemohon tersebut memberikan uang muka (Down Payment) yang relatif besar. Dalam 
hal ini yang menjadi pertimbangan bukan jumlah uang mukanya tetapi kegiatan usaha/pekerjaannya.

d. Tidak memproses pemohon yang tidak memiliki usaha/pekerjaan yang jelas walaupun pemohon tersebut memilih bungan/deposit yang relatif besar.

e. Tidak memproses apabila pemohon baru mendapat pekerjaan pada suatu perusahaan atau baru saja berusaha kurang dari 6 bulan, kecuali karyawan pindahan dari perusahaan atau cabang yang sama.

f. Permohonan kredit yang jelas penggunaannya adalah untuk: diri sendiri, keluarga, operasional perusahaan, dan kendaraan digunakan untuk didaerah pemohon serta tidak digunakan diluar daerah.

g. Pada prinsipnya, apabila pemohon memiliki rumah sendiri yang dibeli baik secara tunai maupun secara kredit maka surveyor harus meminta bukti kepemilikan rumah tersebut. Data ini dapat diperoleh dari proses melihat dokumen rekening listrik/ rekening PAM/ rekening telepon, PBB (Pajak Bumi dan Bangunan), Girik, Akta Jual Beli Notaris, dan Sertifikat Hak Milik.

h. Apabila ada pengajuan pembiayaan dari calon customer/konsumen yang sebelumnya sudah pernah memiliki kontrak dengan PT. Mitra Dana Putra Utama Finance Ujung Batu, maka perlu dianalisa history payment calon customer tersebut, apakah pembayaran angsuran lancar setiap bulannya atau sering tersendat-sendat.
Disamping persyaratan umum pengajuan pembiayaan masih diperlukan persyaratan dokumen-perorangan, yaitu:

a. Kartu Tanda Penduduk (KTP) Suami/Isteri Pemohon. Dokumendokumen tambahan yang diperlukan apabila ada perbedaan KTP dengan kondisi sekarang:

1. Alamat KTP: surat pernyataan beda domisili

2. Status: surat nikah atau surat keterangan nikah

3. Tanda tangan: surat pernyataan perubahan/perbedaan tanda tangan

4. Kadaluwarsa: membuat KTP yang baru atau surat keterangan domisili

b. Kartu Keluarga

Berfungsi untuk menganalisa silsilah keluarga, jumlah tanggungan yang harus dibiayai serta untuk menganalisa benar tidaknya pemohon memiliki hubungan kekeluargaan dengan penjamin bila diperlukan.

c. Slip Gaji atau Surat Keterangan Penghasilan

Dalam menganalisa surat keterangan penghasilan yang perlu diperhatikan adalah jabatan dan penghasilan yang dimilikinya, apakah termasuk golongan pegawai negeri sipil (PNS), POLRI, ABRI, karyawan perusahaan swasta asing atau domestik serta jenis usaha dari masing-masing perusahaan. 
Umul Khair: Analisis Yuridis Perjanjian Pembiayaan Konsumen Dan Akibat Hukum....

d. Bukti kepemilikan ruma atau sewa rumah

Yang diperlukan dalam mengetahui kepemilikan rumah adalah fotocopy dokumen: Sertifikat Hak Milik atau Surat Girik, Rekening Listrik atau Rekening PAM atau Rekening Telepon, Surat PBB, Akta Jual Beli dan Surat Perjanjian Sewa atau kontrak rumah.

e. Rekening Tabungan atau Rekening Koran

Pada saat pemohon/customer memberikan rekening tabungan/rekening koran 3 bulan terakhir maka pemohon juga harus memperlihatkan rekening tabungan/rekening koran asli dan surveyor mengecek apakah fotocopy yang diberikan sesuai dengan aslinya. Apabila fotocopy sesuai dengan aslinya maka surveyor memberikan paraf pada setiap lembar fotocopy rekening tabungan/rekening koran tersebut. Yang perlu diperhatikan dalam rekening koran tersebut adalah pemasukan dan pengeluaran rutin serta saldo rata-rata setiap bulannya.

\section{b. Bentuk dan Isi Perjanjian Pembiayaan}

Kontrak Aplikasi Perjanjian Pembiayaan.

1. Kontrak Aplikasi Perjanjian Pembiayaan mobil bekas semua merek terdiri dari:
a. Lembar Aplikasi Kredit pembiayaan mobil bekas rangkap 3, yang berisi analisa kualitatif dan kuantitatif.

b. Perjanjian Pembiayaan

Konsumen, rangkap 4. Halhal yang harus dijelaskan kepada pemohon/customer pada saat penandatanganan lembar perjanjian pembiayaan ini adalah tentang denda setiap keterlambatan pembayaran angsuran dan tentang larangan mengalihkan, menggadaikan atau menyewakan barang jaminan kepada pihak lain sebelum kredit lunas.

c. Form Perjanjian Pemberian Jaminan Fidusia rangkap 4, yang artinya penyerahan hak milik secara kepercayaan kepada konsumen tetapi bukti kepemilikannya dipegang oleh PT. Mitra Dana Putra Utama finance Ujung Batu.

d. Surat Kuasa Penarikan dan Asuransi Kendaraan 1 lembar.

e. Form Perubahan Perjanjian Pembiayaan Konsumen tentang Biaya Tagih, rangkap 2.

f. Surat Pernyataan rangkap 2, mengenai ketentuan-ketentuan asuransi yang hanya menjamin kerugian akibat pencurian saja, atau kerusakan akibat kecelakaan berat yang menimbulkan kerusakan parah lebih dari $75 \%$ dari kondisi semula.

g. Surat Pernyataan dan Konfirmasi, rangkap 2.

h. Surat Persetujuan Suami/Isteri, rangkap 2. 

i. Surat Pernyataan tentang Perubahan Tanda Tangan, rangkap 2
j. Surat Persetujuan Suami/Isteri, rangkap 2.

\section{Akibat Hukum jika terjadi Wanprestasi dalam Perjanjian Pembiayaan Konsumen di Indonesia}

Dalam pelaksanaan perjanjian pembiayaan konsumen tidak terlepas dari konsekuensi hukum tersebut di atas. Oleh karena dalam pelaksanaannya pasti akan menemukan banyak kesalahan ataupun kelalaian dari salah satu pihak sehingga terhadapnya dapat dikenakan pertanggungjawaban akan akibat hukum yang terhadap suatu kesalahan atau kelalaian. Perlu dipahami bahwa dalam suatu perjanjian pembiayaan konsumen dalam bentuk apapun, berarti kedua belah pihak saling mengikatkan dirinya untuk melaksanakan sesuatu yang telah diperjanjikan (prestasi). Namun dalam kenyataan yang ada tidak menutup kemungkinan dapat terjadi bahwa salah satu pihak tidak melaksanakan apa yang telah diperjanjikan.

Berakhirnya perjanjian pembiayaan konsumen ini sesuai dengan kesepakatan para pihak sehingga sudah barang tentu disini terdapat kemungkinan cara untuk mengakhirinya. Adapun kemungkinankemungkinan yang dapat dijadikan cara untuk mengakhiri suatu perjanjian tersebut:

1. Apabila angsuran telah dibayar lunas;
2. Apabila salah satu pihak meninggal dunia dan tidak ada ahli warisnya yang meneruskan, atau mungkin ada ahli warisnya yang namun tidak mau meneruskan;

3. Apabila terjadi perampasan barang yang menjadi obyek perjanjian pembiayaan konsumen

4. Apabila setelah adanya putusan dari pengadilan yang bersifat tetap.

Perjanjian dalam pelaksanaannya memungkinkan untuk tidak terlaksana atau tidak sempurna, baik karena kesalahan maupun karena kekuatan memaksa namun adakalanya perjanjian tidak terlaksana sepenuhnya seperti yang disepakati bahkan perjanjian dapat pula tidak terlaksana sama sekali. Kondisi tidak terlaksanakanya perjanjian tersebut dikenal dengan istilah wanprestasi. Wanprestasi adalah tidak dilaksanakannya prestasi atau kewajiban sebagaimana mestinya yang dibebankan oleh kontrak terhadap pihak-pihak tertentu seperti yang disebutkan dalam kontrak.

Ada 4 akibat adanya wanprestasi, sebagaimana telah dikemukakan berikut ini.

1. Perikatan tetapa ada Kreditur masih dapat menuntut kepada debitur pelaksanaan prestasi, apabila ia terlambat memenuhi prestasi. Disamping itu kreditur berhak untuk menuntut ganti rugi akibat keterlambatan melaksanakan prestasinya. 
Umul Khair: Analisis Yuridis Perjanjian Pembiayaan Konsumen Dan Akibat Hukum....

2. Debitur harus membayar ganti rugi kepada kreditur (Pasal 1243 KUH Perdata).

3. Beban resiko beralih untuk kerugian debitur jika halangan itu timbul setelah debitur wanprestasi, kecuali bila ada kesengajaan atau kesalahan besar dari pihak kreditur, oleh karena itu debitur tidak dibebankan untuk berpegang pada keadaan memaksa.

4. Jika perikatan lahir dari perjanjian timbal balik, kreditur dapat membebaskan diri dari kewajiban memberikan kontra prestasi dengan menggunakan Pasal 1266 KUH Perdata.

Ada dua sebab timbulnya ganti rugi, yaitu ganti rugi karena wanprestasi dang anti rugi karena perbuatan melawan Hukum. Ganti rugi karena wanprestasi diatur dalam Buku III KUH Perdata, yang dimulai dari Pasal 1243 KUH Perdata s.d. Pasal 1252 KUH Perdata, sedangkan ganti rugi karena perbuatan melawan Hukum diatur dalam Pasal 1365 KUH Perdata. ${ }^{2}$

Menurut pasal 1365 KUH Perdata, tiap perbuatan melanggar hukum yang membawa kerugian pada seorang lain, mewajibkan orang yang karena salahnya menerbitkan kerugian itu, mengganti kerugian tersebut. Wanprestasi seorang debitur dapat berupa:

a. Ada perbuatan melanggar hukum

b. Ada kerugian

2 http/www.wanperstasi dan anti rugi.htmblog.spot.didown load pada kamis tanggal 26 Januari 2017 jam 10.00 WIB c. Ada hubungan kausalitas antara kerugian dan perbuatan melanggar Hukum

d. Ada kesalahan.

Wujud dari tidak memenuhi prestasi tersebut ada 3 macam, yaitu:

1. Debitur sama sekali tidak memenuhi perikatan.

2. Debitur terlambat memenuhi perikatan.

3. Debitur keliru atau tidak pantas memenuhi perikatan.

Akibat yang sangat penting dari tidak dipenuhinya perjanjian adalah bahwa kreditur dapat meminta ganti kerugian atas ongkos, rugi dan bunga yang dideritanya. Untuk adanya kewajiban ganti rugi bagi debitur maka undang-undang menentukan bahwa harus terlebih dahulu dinyatakan dalam keadaan lalai. Berada dalam keadaan lalai adalah peringatan atau pernyataan dari kreditur tentang saat selambatlambatnya debitur wajib memenuhi prestasi, apabila saat ini dilampauinya maka debitur dinyatakan wanprestasi. Dan oleh karena perjanjian pembiayaan konsumen merupakan perjanjian innominaat yang didasarkan pada pasal 1319 KUH Perdata, maka harus tunduk juga pada ketentuan umum perjanjian, misalnya mengenai syarat sahnya suatu perjanjian dan wanprestasi. Wujud wanprestasi yang lebih mudah ditentukan momen atau saat terjadinya adalah perbuatan yang dilarang dalam kontrak, karena jika seorang debitur atau pihak yang mempunyai kewajiban melaksanakan prestasi dalam kontrak itu 
melaksanakan perbuatan yang dilarang dalam kontrak maka dia tidak melaksanakan prestasinya.Momen/saat terjadinya wanprestasi disimpulkan dari subtansi Pasal 1243 KUH Perdata.

Suatu wanprestasi baru terjadi jika debitor atau pihak yang mempunyai kewajiban melaksanakan prestasi dalam kontrak, dinyatakan lalai (in mora steliiing ingebreke stelling) untuk melaksanakan restasinya atau dengan kata lain wanprestasi ada jika debitor atau pihak yang mnempunyai kewajiban melaksanakan prestasi dalam kontrak tersebut tidak dapat membuktikan bahwa ia telah melakukan wanprestasi itu diluar kesalahannya atau karena keadaan memaksa. Jadi "pernyataan lalai" adalah suatu rechtmiddel atau upaya hukum kontrak (vide KUH Perdata) untuk sampai kepada tahap debitor atau pihak yang mempunyai kewajiban melaksanakan prestasi dan kontrak tersebut dinyatakan "wanprestasi".

Akibat munculnya wanprestasi ialah timbulnya hak pada pihak yang dirugikan untuk menuntut penggantian kerugian yang dideritanya terhadap pihak yang wanprestasi. Pihak yang wansprestasi memiliki kewajiban untuk membayar ganti rugi kepada pihak yang menderita kerugian. Pasal 1340 ayat (1) Kitab Undang-Undang Hukum perdata menuyatakan bahwa perjanjianperjanjian yang dibuat hanya berlaku di antara para pihak yang membuatnya. Ini berarti bahwa setiap perjanjian, hanya membawa akibat berlakunya ketentuan pasal 1131 Kitab Undang-Undang
Hukum Perdata bagi para pihak yang membuat perjanjian tersebut. Jadi apa yang menjadi kewajiban atau prestasi yang harus dilaksanakan oleh debitor dalm perjanjian hanya merupakan dan menjadi kewajibanya semata-mata.

Dalam hal terdapat seorang pihak ketiga yang kemudian hari melaksanakan kewajibannya tersebut kepada kreditor, maka ini tidak berarti debitor dilepaskan atau dibebaskan dari kewajibannya tersebut.

Jadi akibat hukumnya jika terjadi wanprestasi, maka perjanjian tersebut tidak perlu dimintakan pembatalan, tapi dengan sendirinya sudah batal demi, namun ketentuan Pasal 1266 ayat 2 menjelaskan bahwa akibat hukum wanprestasi tidak batal demi hukum, namun harus dimintakan pembatalan kepada hakim. Dari hasil penelitian dapat ditarik kesimpulan bahwa dasar penerapan perjanjian sewa beli yaitu, Pasal 1 huruf a Keputusan Menteri Perdagangan dan Koperasi Nomor 34/KP/II/80 Tentang Perijinan Sewa beli (Hire Purchase) Jual Beli Dengan Angsuran, dan Sewa (Renting). Akibat hukumnya jika terjadi wanprestasi, maka perjanjian tersebut tidak perlu dimintakan pembatalan, tapi dengan sendirinya sudah batal. Namun ketentuan Pasal 1266 ayat 2 menjelaskan bahwa akibat hukum wanprestasi tidak batal demi hukum, namun harus dimintakan pembatalan kepada hakim. Selanjutnya Pasal 1244 dan Pasal 1252 KUH Perdata menjelaskan mengenai ganti rugi atas wanprestasi yaitu, dengan membayar 
Umul Khair: Analisis Yuridis Perjanjian Pembiayaan Konsumen Dan Akibat Hukum....

kerugian nyata yang dialami, ongkosongkos yang digunakan, serta dibolehkan untuk menuntuk kehilangan keuntungan yang di harapkan.

\section{KESIMPULAN}

1. Pengertian lembaga keuangan bukan bank dapat dilihat dalam Pasal 1 angka (4) Keputusan Presiden Republik Indonesia Nomor 61 Tahun 1988 tentang Lembaga Pembiayaan, Lembaga Keuangan bukan bank adalah badan usaha yang melakukan kegiatan di bidang keuangan yang secara langsung atau tidak langsung menghimpun dana dengan jalan mengeluarkan surat berharga dan menyalurkannya ke dalam masyarakat guna membiayai investasi perusahaan-perusahaan.

Dasar penerapan pembiayaan konsumen Berdasarkan Keputusan Menteri Keuangan Nomor 448/KMK.017/2000 Tentang Perusahaan Pembiayaan Konsumen dijelaskan bahwa pembiayaan konsumen sebagai suatu kegiatan yang "dilakukan dalam bentuk penyediaan dana bagi konsumen untuk pembelian barang yang pembayarannya dilakukan secara angsuran atau berkala oleh konsumen".Kegiatan pembiayaan dilakukan melalui system pemberian kredit yang pembayarannya oleh konsumen dilakukan secara angsuran atau berkala. Juga perjanjian pembiayaan konsumen merupakan perjanjian baku/perjanjian standar.
2. Akibat hukumnya jika terjadi wanprestasi, maka perjanjian tersebut tidak perlu dimintakan pembatalan, tapi dengan sendirinya sudah batal demi hukum. Namun ketentuan Pasal 1266 ayat 2 menjelaskan bahwa akibat hukum wanprestasi tidak batal demi hukum, namun harus dimintakan pembatalan kepada hakim. Selanjutnya Pasal 1244- Pasal 1252 KUH Perdata menjelaskan mengenai ganti rugi atas wanprestasi yaitu, dengan membayar kerugian nyata yang dialami, ongkos-ongkos yang digunakan, serta dibolehkan untuk menuntuk kehilangan keuntungan yang di harapkan. Selanjutnya tuntutan dapat dimintakan lebih jelas diatur dalam Pasal 1267 KUH Perdata.

\section{SARAN}

Diharapkan bagi para pihak haruslah lebih berhati-hati dan teliti dalam memahami dan meksanakan perjanjian pembiayaan konsumen khusunya bagi pihak debitur agar tidak terjadi hal-hal yang merugikan diri sendiri. Dan bagi para pihak haruslah dengan itikad baik dalam melakukan perjanjian pem jangan dengan adanya paksaan dan tipu muslihat. Dan sebaiknya dalam melakukan perjanjian sewa beli harus dilakukan secara tertulis agar lebih aman dan ada kepastian hukumnya, yang kedepan apabila terjadi permasalahan, itu dapat digunakan sebagai alat bukti. . Bagi pemerintah diharap kedepan telah dibuat undang-undang khusus yang 
mengatur tentang Perjanjian pembiayaan konsumen agar lebih jelas mengenai dasar hukum dan dasar pelaksanaannya. Serta bagi hakim agar dalam penyelesaian perkara pembiayaan konsumen haruslah memperhatikan asas keseimbangan karena mengingat pada posisinya pihak kreditur berada pada posisi yang lemah.

\section{UCAPAN TERIMAKASIH}

Puji dan Syukur penulis ucapkan ke hadirat Allah SWT yang telah memberikan Rahmat dan Karunia-Nya, sehingga akhirnya penulis dapat menyelesaikan penulisan karya ilmiah ini yang berjudul: "ANALISIS YURIDIS PERJANJIAN PEMBIAYAAN KONSUMEN DAN AKIBAT HUKUM JIKA TERJADI WANPRESTASI DALAM PERJANJIAN PEMBIAYAAN KONSUMENI DI INDONESIA,

Penulis menyadari bahwa tanpa bantuan dan dorongan dari berbagai pihak tidak mungkin karya ilmiah ini dapat diselesaikan. Oleh karena itu pada kesempatan ini dengan segala kerendahan hati, penulis ingin mengucapkan terimakasih dan penghargaan yang sebesar-besarnya kepada:

1. Bapak Dr.Eviandi Ibrahim S.H.,M.Hum selaku Ketua Sekolah Tinggi Ilmu Hukum Putri Maharaja Payakumbuh

2. Seluruh rekan-rekan Dosen Sekolah Tinggi Ilmu Hukum Putri Maharaja yang tidak dapat penulis sebutkan satu-persatu.

\section{DAFTAR PUSTAKA}

Ahmadi Miru, 2008, Hukum Perikatan, Rajawali Pers

C.S.T. Kansil, 2008, Modul Hukum Perdata Termasuk Asas-Asas Hukum Perdata, Jakarta Pradnya paramita

Djaja S. Meliala, 2012 ,Hukum perjanjian khusus, Nuansa Aulia, Bandung

Gunawan Widjaja dan Kartini Wuljadi, 2003, Hapusnya perikatan, Jakarta, PT Raja Grafindo Persada

Kartini Muljadi \& Gunawan Widjaja, 2004, Perikatan yang lahir dari perjanjian, PT Raja Grafindo Persada, Jakarta

Muhammad Syaihfuddi, 2012, Hukum Kontrak, Mandar Maju, Bandung.

Munir Fuady, 2002, Hukum Tentang Pembiayaan Dalam Teori dan Praktek, Bandung: PT. Citra Aditya Bakti,.

R. Subekti, 1995, Aneka Perjanjian, Citra Aditya Bakti, Bandung. Intermasa, Jakarata.

Ricardo Simanjuntak, 2006, Hukum Kontrak Teknik Perancangan Kontrak Bisnis, PT. Gramedia, Jakarta.

Retnowulan Sutantio, 1994, Perjanjian Pembiayaan Konsumen, Jakarta: Dalam Pustaka Peradilan Proyek Pembinaan Tehnis Yustisial Mahkamah Agung RI,

R. Setiawan, 1994, Pokok-Pokok Hukum Perikatan, Bandung: PT. Bina Cipta.

R. Wirjono Prodjodikoro, 1993, AzasAzas Hukum Perjanjian, Bandung: Sumur,.

Ronny Hanitijo Soemitro, 1988, Metodologi Penelitian Hukum dan 
Umul Khair: Analisis Yuridis Perjanjian Pembiayaan Konsumen Dan Akibat Hukum....

Jurimetri, Jakarta: Ghalia Indonesia,.

Salim H.S, 2008, Perkembangan Hukum Kontrak Innominaat, Sinar Grafika, Jakarta,.

Suharnoko,2004, Hukum

Perjanjian.Teori Dan Analisis

Kasus, Jakarta Kencana

Salim H.S, 2013, Hukum Kontrak (teori dan teknik penyusunan kontrak) Sinar Grafika, Jakarta.

Peraturan Perundang-Undangan

Undang-Undang Nomor: 10 Tahun 1998 Tentang Pokok-Pokok Perbankan.

Undang-Undang Nomor: 42 Tahun 1999 Tentang Jaminan Fidusia.

Keputusan Presiden Republik Indonesia Nomor: 61 Tahun 1988 Tentang Lembaga Pembiayaan.

Keputusan Menteri Keuangan Republik Indonesia Nomor: 1251/KMK.013/1988 Tentang Ketentuan Dan Tata Cara Pelaksanaan Lembaga Pembiayaan.

Keputusan Menteri Keuangan Republik Indonesia Nomor: 448/KMK.017/2000 Tentang Perusahaan Pembiayaan.

Sumber lain :

http/www.Law and Heart WANPRESTASI DALAM PERJANJIAN PEMBIAYAAN KONSUMEN htmblog.spot.

http/www.wanprestasi dan ganti rugi.htmblog.spot. 